\begin{tabular}{c|c|c}
\hline \hline Vol. 50: 233-235, 2002 & DISEASES OF AQUATIC ORGANISMS \\
Dis Aquat Org & Published July 29 \\
\hline
\end{tabular}

\title{
NOTE
}

\section{First isolation of largemouth bass virus}

\author{
John M. Grizzle ${ }^{1, *}$, Ilhan Altinok ${ }^{1}$, William A. Fraser ${ }^{2}$, Ruth Francis-Floyd ${ }^{3}$ \\ ${ }^{1}$ Southeastern Cooperative Fish Disease Project, Department of Fisheries and Allied Aquacultures, Auburn University, Auburn, \\ Alabama 36849, USA \\ ${ }^{2}$ Florida Department of Agriculture and Consumer Service, Kissimmee, Florida 34741, USA \\ ${ }^{3}$ Department of Large Animal Clinical Science, University of Florida, Gainesville, Florida 32653, USA
}

\begin{abstract}
The first reported fish kill caused by largemouth bass virus (LMBV) occurred in 1995 in Santee-Cooper Reservoir, South Carolina, USA. Subsequently, this iridovirus has been implicated in additional fish kills and has also been found in clinically healthy fish in numerous locations in the southeastern USA. We compared the virus from SanteeCooper Reservoir with a virus isolated in 1991 from largemouth bass, Micropterus salmoides, from Lake Weir, Florida. Restriction fragment length polymorphisms and the DNA sequence of a portion of the major capsid protein gene were identical for the South Carolina and Florida isolates. These results establish that LMBV was first found in Florida, rather than South Carolina. We propose that the name largemouth bass virus continue to be used for this virus, rather than alternative names based on geographical origin.
\end{abstract}

KEY WORDS: Iridovirus · Micropterus salmoides · Discovery · History $\cdot$ Polymerase chain reaction

Resale or republication not permitted
without written consent of the publisher

Largemouth bass virus (LMBV) is an iridovirus that affects largemouth bass Micropterus salmoides. Fish with the disease caused by this virus lose equilibrium, have enlarged or reddened swim bladders, and tend to float near the surface (Plumb et al. 1996); however, largemouth bass infected with LMBV are often clinically normal (Plumb et al. 1999). The first fish kill implicating LMBV as a pathogen occurred in SanteeCooper Reservoir, South Carolina, during 1995 (Plumb et al. 1996), and the pathogenicity of this virus was confirmed by Plumb \& Zilberg (1999). Molecular characterization indicated that LMBV is closely related to 2 other iridoviruses, guppy virus (GV) and doctorfish virus (DFV), but is distinct from frog virus 3 (Mao et al. 1999).

*E-mail: jgrizzle@acesag.auburn.edu
An iridovirus was isolated from largemouth bass in 1991 following sporadic fish kills and declining numbers of largemouth bass and black crappie Pomoxis nigromaculatus in Lake Weir, Florida (Francis-Floyd 1992). This iridovirus was later isolated from clinically normal largemouth bass from Lake Weir and also from Lake Holly, which had no history of fish kills and was considered a relatively pristine site. Agar gel immunodiffusion of fish sera indicated that $70 \%$ of largemouth bass sampled from Lake Weir $(\mathrm{N}=20)$ and $68 \%$ of largemouth bass sampled from Lake Holly $(\mathrm{N}=19)$ were seropositive for the iridovirus isolated from Lake Weir.

The objective of our study was to genetically compare the iridoviruses isolated from largemouth bass in 1991 from Lake Weir, Florida (Francis-Floyd 1992), and in 1995 from Santee-Cooper Reservoir, South Carolina (Plumb et al. 1996).

Materials and methods. Bluegill fry-2 (BF2) cells were grown at $30^{\circ} \mathrm{C}$ in Eagle's minimum essential medium supplemented with $10 \%$ fetal calf serum. These cells were inoculated with the virus isolates reported by Francis-Floyd (1992) and Plumb et al. (1996). When a cytopathic effect was detected, cells and culture fluid were centrifuged at $15000 \times g$ for $10 \mathrm{~min}$, and the pellet was resuspended in Tris EDTA (TE) buffer (10 mM Tris-HCl and $0.1 \mathrm{mM}$ EDTA, pH 8). Lysis buffer (200 mM NaCl, 10 mM Tris-HCl, pH 8.0, $1 \%$ sodium dodecyl sulfate, and $50 \mathrm{mM}$ EDTA) and Proteinase $\mathrm{K}$ were added, and samples were incubated at $65^{\circ} \mathrm{C}$ overnight. The DNA was extracted with phenol-chloroform, precipitated with ethanol at $-20^{\circ} \mathrm{C}$, and resuspended in TE buffer.

The 5' end of the major capsid protein gene was amplified with the polymerase chain reaction (PCR) method of Woodland et al. (2002). The primers we used 


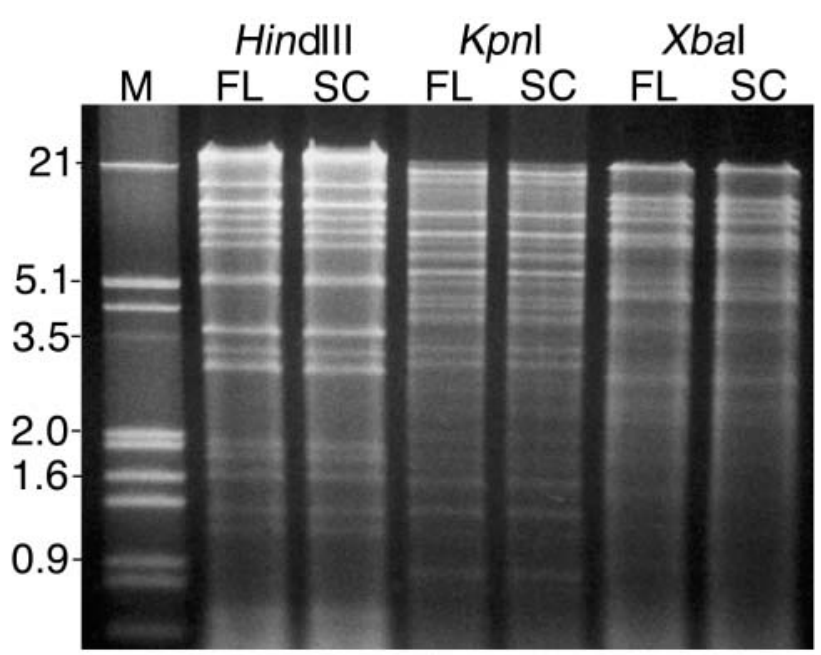

Fig. 1. Restriction fragment length polymorphisms of viral DNA digested with HindIII, KpnI, or XbaI. One viral isolate was from Santee-Cooper Reservoir, South Carolina (SC), and the other was from Lake Weir, Florida (FL). Both isolates were from largemouth bass, Micropterus salmoides. Restriction fragments were separated by electrophoresis, with one lane (M) for kilobase-pair size markers, and were visualized by ethidium bromide staining

for PCR (forward: 5'-GAC TTG GCC ACT TAT GAC; reverse: 5'-GTC TCT GGA GAA GAA GAA) amplify a 495 base-pair (bp) region (Plumb et al. 1999). This highly conserved region was selected because it has been found to be suitable for comparison of closely related iridoviruses (Tidona et al. 1998) and because sequence information was available for several isolates of LMBV (Plumb et al. 1999). The PCR products were purified with a QIAquick PCR purification kit (Qiagen) before sequencing, electrophoresed in $1 \%$ agarose to check purity, and quantified spectrophotometrically. The purified PCR products were directly sequenced with an ABI PRISM 3100 genetic analyzer (Applied Biosystems). Both strands of templates were sequenced. The derived nucleotide sequences were analyzed and aligned with BioEdit Sequence Alignment Editor (North Carolina State University, Raleigh, North Carolina, USA).

For analysis of restriction fragment length polymorphisms (RFLP), the viral DNA was prepared as described above, except that the infected BF2 cells in TE buffer were homogenized, centrifuged at $2500 \times g$ for $10 \mathrm{~min}$, and the supernatant was used as the source of viral DNA. Aliquots of purified viral DNA were digested with the restriction endonucleases HindIII, $K p n I$, or $X b a I$ for $3 \mathrm{~h}$ at $37^{\circ} \mathrm{C}$. Digested DNA was electrophoresed in $0.5 \%$ agarose gels and stained with ethidium bromide. Size markers were Lambda DNA/ EcoR I + HindIII (Promega).
Results and discussion. The PCR amplified a $495 \mathrm{bp}$ DNA segment of the viral isolates from Santee-Cooper Reservoir and Lake Weir, and the DNA sequences of the amplified region were identical for both isolates. This DNA sequence was also identical to the sequence previously reported for LMBV from Santee-Cooper Reservoir and 5 locations in Alabama, Georgia, and Mississippi (Mao et al. 1999, Plumb et al. 1999, Hanson et al. 2001).

Digestion of viral DNA with the restriction endonucleases HindIII, KpnI, or XbaI revealed that the RFLP profiles for the isolates from Santee-Cooper Reservoir and Lake Weir were identical (Fig. 1). The profiles after digestion with $\mathrm{HindIII}$ or $\mathrm{XbaI}$ were also the same as previously shown for LMBV from Santee-Cooper Reservoir (Mao et al. 1999).

The identical partial DNA sequence and RFLP profiles of these 2 viral isolates indicate that LMBV was isolated from clinically normal largemouth bass in Florida before it was found in Santee-Cooper Reservoir, South Carolina. Largemouth bass are moved between states by state and federal biologists as well as by private anglers. Therefore, largemouth bass virus could have been transported from Florida to other states, but it is also possible that the virus was introduced to Florida by the southward movement of fish by agencies or the general public. It is unclear at present whether largemouth bass virus is a new pathogen that is being spread through the movement of fish and water, or whether it is a recently recognized agent that is being found more frequently because of increased testing. Until a better understanding of this virus and associated disease is realized, it is prudent to use discretion when moving fish.

The discovery of LMBV in Lake Weir, Florida, before its isolation from Santee-Cooper Reservoir, also has implications regarding the name of this virus. Mao et al. (1999) suggested that LMBV, DFV, and GV are different isolates or strains of a new species of ranavirus and that this species be named Santee-Cooper ranavirus. This name was based on the proposal that iridoviruses be named for the 'geographical origin' of the original isolate (Williams 1996). However, our results indicate that the name proposed by Mao et al. (1999) is not appropriate because the virus was isolated earlier from another location. There is also some question about whether GV and DFV are ranaviruses (Hyatt et al. 2000). Until the history, biology, and relationships of these viruses are better established, the virus reported by Francis-Floyd (1992) and Plumb et al. (1996) should continue to be known as largemouth bass virus.

Acknowledgements. This research was supported by the Southeastern Cooperative Fish Disease Project. The manuscript was reviewed by J. A. Plumb, C. J. Brunner, and A. D. Noyes. 


\section{LITERATURE CITED}

Francis-Floyd R (1992) Comparative hematology for largemouth bass (Micropterus salmoides) and black crappie (Pomoxis nigromaculatus) from Lake Weir, Lake Holy, and Newman's Lake. Final Report. Florida Freshwater Game and Fish Commission, Tallahassee, FL

Hanson LA, Petrie-Hanson L, Meals KO, Chinchar VG, Rudis $M$ (2001) Persistence of largemouth bass virus infection in a northern Mississippi reservoir after a die-off. J Aquat Anim Health 13:27-34

Hyatt AD, Gould AR, Zupanovic Z, Cunningham AA, Hengstberger S, Whittington RJ, Kattenbelt J, Coupar BEH (2000) Comparative studies of piscine and amphibian iridoviruses. Arch Virol 145:301-331

Mao J, Wang J, Chinchar GD, Chinchar VG (1999) Molecular characterization of a ranavirus isolated from largemouth bass Micropterus salmoides. Dis Aquat Org 37:107-114

Editorial responsibility: Jo-Ann Leong, Corvallis, Oregon, USA
Plumb JA, Zilberg D (1999) The lethal dose of largemouth bass virus in juvenile largemouth bass and the comparative susceptibility of striped bass. J Aquat Anim Health 11: $246-252$

Plumb JA, Grizzle JM, Young HE, Noyes AD, Lamprecht S (1996) An iridovirus isolated from wild largemouth bass. J Aquat Anim Health 8:265-270

Plumb JA, Noyes AD, Graziano S, Wang J, Mao J, Chinchar VG (1999) Isolation and identification of viruses from adult largemouth bass during a 1997-1998 survey in the southeastern United States. J Aquat Anim Health 11:391-399

Tidona CA, Schnitzler P, Kehm R, Darai G (1998) Is the major capsid protein of iridoviruses a suitable target for the study of viral evolution? Virus Genes 16:59-66

Williams T (1996) The iridoviruses. Adv Virus Res 46:345-412

Woodland JE, Noyes AD, Grizzle JM (2002) A survey to detect largemouth bass virus among fish from hatcheries in the southeastern USA. Trans Am Fish Soc 131:308-311

Submitted: October 27, 2001; Accepted: February 17, 2002 Proofs received from author(s): July 10, 2002 